\title{
XXXXXXXXXX
}

\section{THE WAGELESS LIFE OF THE SUBALTERN}

\begin{abstract}
One of the most striking political and intellectual legacies of the Subaltern Studies project has been the innovative methodologies and archives that it has mobilized to articulate the singular position of the subaltern outside the hegemonic terms of representation. Yet in its sweeping classification of non-hegemonic social groups and classes, Subaltern Studies has often tended to elide the precise economic determinants that define the subaltern as a class, and thereby foreclose the forms of agency that are available to people who occupy such singular positions of radical alterity that cannot be identified in hegemonic terms. Gayatri Spivak’s deconstructive rethinking of the labor theory of value in 'Scattered Speculations on the Question of Value' (1985) enables us to consider how the body of the gendered subaltern performs an important economic function in the contemporary global economy. But to what extent can such a theory account for the economic conditions of people dwelling in the slums and shantytowns of postcolonial cities, or what Michael Denning has aptly called the wageless life of the global poor? And how might we begin to address the gendered dynamics of wageless life? Through a reading of Abderrahmane Sissako’s film Bamako (2006), this essay considers how the film’s juxtaposition of a fictional courtroom narrative in which the World Bank is put on trial and the everyday lives of characters who populate the courtyard in which the courtroom is situated raise questions about the limitations of the law and civil society to alter the socio-economic conditions of wageless life. With reference to Gayatri Spivak's reflections on the relationship between the subaltern and the economic policies of global financial institutions such as the World Bank and the International Monetary Fund, the essay suggests that the narrative structure and mise-en-scène of Bamako offer
\end{abstract}


a means of addressing the global economic conditions as well as the power relations that circumscribe the agency and voice of the subaltern.

Keywords: Abderrahmane Sissako’s Bamako; subaltern; World Bank; structural adjustment; wageless life; civil society

During an early sequence in Abderrahmane Sissako’s film Bamako (2006), an old man called Zegué Bamba tries to take the stand of a makeshift court in a courtyard. This man does not seem to understand the rituals of this improvised courtroom - a court that has been established to hear a public case against the World Bank. One of the court officials upbraids the man for attempting to take the stand when it is not his turn to speak, and the judge advises him to step down. In this way, the scene can appear to enact the legal authority of the judge and to legitimate the space of the courtroom. Yet the scene also serves to highlight the incommensurability between the specialized legal language of the courtroom and the situated knowledge of the man's understanding of the power of words when they are articulated in public. A sense of this situated knowledge is conveyed in the man's assertion that 'words are something. They can seize you in the heart. But it's not good to keep them inside'. Yet the cultural and political meanings of the man's reflections on the public use of language are left suspended at this point in the film's narrative.

This scene is significant for a number of reasons. First, it highlights the challenge of finding an appropriate public language and voice in which to challenge and contest the neoliberal economic policies of the World Bank and the International Monetary Fund. Within the specific context of Mali, these policies have involved reducing public sector expenditure in banking and 
education, promoting private sector investment in areas such as agriculture, and currency devaluation (International Monetary Fund). Second, the scene draws attention to the limitations of the dominant institutions of civil society - symbolized by the court - in doing justice to the social and economic suffering wrought by the repressive conditions imposed on countries accepting World Bank loans. Third, it raises questions about the possibilities and limitations of representation for disempowered and disenfranchised constituencies in the Global South - a concern that is echoed in many subsequent scenes. In this sense, the film's overtly political concerns are close to those of historians, social scientists, anthropologists, activists and cultural critics associated with the Subaltern Studies collective. Yet, as I will go on to suggest, the film's movement between events taking place in the space of the court and events in the space of the courtroom also encourage viewers to reflect on what it means to be a wageless subject of debt under neoliberal finance capitalism, and to what extent the theories and methodologies of the Subaltern Studies collective can account for that condition.

On a first viewing, Bamako is an experimental fiction film. Part courtroom drama, part crime drama, part western, the film moves between the public space of an improvised courtroom and the domestic spaces of a residential courtyard in which the film is situated. The courtroom drama stages a trial in which various witnesses from Malian society, including an unemployed schoolteacher, a peasant farmer, and a former Minister of Culture try to hold the World Bank to account for the destructive effects of its policies of structural adjustment and currency devaluation on the social fabric of Mali. The testimonies of these witnesses are in turn contested by a European lawyer who speaks in defense of the World Bank. In parallel with this narrative, the film focuses on the lives of a young married couple called Chaka and Melé, who live with their child in the same courtyard. In tracing the vicissitudes of their relationship, the film suggests that Chaka's unemployment is a significant contributing factor in the breakdown of their 
marriage. This narrative ends with Chaka taking his own life with a gun, which, the film suggests, he has stolen from a police observer who is present at the trial. These two parallel narratives are in turn interrupted by a film-within-a-film, which is broadcast on a television being watched by another family in the courtyard. This film - entitled Death in Timbuktu - is an ‘African western’ which features the American actor Danny Glover, the Palestinian director Elia Suleiman, and the director of Bamako, Abderrahmane Sissako. The juxtaposition of these discontinuous narrative threads may seem to undermine the coherence of the courtroom narrative. Yet, as I go on to suggest, these different narrative elements also raise questions about the limitations of the law and civil society to alter the conditions of wageless life under neoliberal regimes of structural adjustment.

Zegué Bamba’s untimely appearance and subsequent dismissal from the stand of the courtroom near the beginning of the film parallels other instances of silencing and proscription in the filmic narrative of Bamako. The former schoolteacher, Samba Diakité, is either unable or unwilling to testify about losing his post at a local school. When he takes the stand in the court, Diakité remains motionless before the judge and does not utter a word. As I go on to suggest, this non-verbal gesture could be read as a sign of a lack of confidence in the power of public speaking and the institutions of civil society to challenge the economic policies of the World Bank. In a similar vein, the unemployed character, Chaka, who lives in the courtyard where the trial takes place, decides not to speak again about the after-effects of structural adjustment when the sound recording engineer accidentally erases his words. As Chaka puts it to the sound engineer as he prepares the equipment for another recording: 'No one will listen. Don't waste your time'. These examples of witnesses who have no faith in the act of speaking about the economic circumstances of an indebted, wageless life highlight the rhetorical aporia that Gayatri Spivak diagnosed in her reflections on and revisions to the essay 'Can the Subaltern Speak?' As Spivak has suggested in 
an interview with Donna Landry, the point is not that the subaltern cannot speak in the simple sense of locution; it is rather that her words cannot be heard or recognized in the dominant idiom of the public sphere (Spivak 1996). When such an account of subalternity is abstracted from its specific historical circumstances, it can work to elide the socio-economic determinants that prevent the subaltern from being heard or recognized. In 'Can the Subaltern Speak?' (1988), Spivak was concerned with the singular position of the gendered subaltern subject of sati-suicide and the ways in which her agency and voice were in effect proscribed by both Hindu pundits and British reformers in debates over the practice of sati-suicide in $19^{\text {th }}$-century India. In this respect, Spivak's use of the term subaltern to describe a singular gendered figure differs from Antonio Gramsci's use of the term as a generic category to describe subaltern classes and social groups who have no access to the state or civil society (Young, p. 31). This is not to suggest, however, that the two uses of the term are necessarily mutually exclusive. As Spivak points out in a discussion with Baidik Bhattacharya about the ways in which Ranajit Guha and the South Asian Subaltern Studies collective made use of Gramsci, one of Gramsci's most valuable insights regarding the subaltern was the location of a subject outside of capital logic (2012, p. 222). Such a subject may not be part of a social class in the sense of the waged, industrial proletariat, as it has been conventionally understood in Marxist social theory. Yet the singular experience of exclusion from capital logic can shed light on the socio-economic conditions specific to contemporary forms of unwaged, precarious life under neoliberal global capitalism. Indeed, the movement from singular narratives of exclusion to the socio-economic conditions of subalternity is particularly apparent in Sissako's use of multiple focalization in Bamako to evoke a social world that has been devastated by the World Bank's policies of structural adjustment and currency devaluation, as we will see. 
The despair and pessimism of Samba Diakité and Chaka about the limitations of speaking publicly about structural adjustment and its impact on the infrastructure and social fabric of Mali can certainly be understood as a lack of faith in the political efficacy of representation. Yet there is also a certain sense in which the words of Zegué Bamba and his understanding of the value of words offer a counterpoint to this scene of representation. In a later scene in which he takes the stand, Zegué Bamba delivers his testimony as an oral performance. By leaving his words untranslated and without subtitles, the director encourages viewers to attend to this man's bodily movements and the accusatory tone of the words that are in his heart. The self-conscious use of subtitles in this scene also foregrounds the potential distance between the language and rhetoric of the speakers that take the stand in the frame of the film and the dominant global languages of the international cinema audiences who view the film. According to the Internet Movie Database, Bamako was first screened at a number of European and North American film festivals; of the list of documented release dates, only one African film festival is mentioned: the prestigious Ouagadougou Panafrican Film and Television Festival in Burkina Faso (2007). Even if this data excluded certain film festivals, the prevalence of North American and European release dates suggests that Bamako was primarily marketed as a foreign-language film for a non-Bambaraspeaking international audience.

It is also worth noting that the actor who played Zegué Bamba is a farmer and a griot from southern Mali, who Sissako employed as a non-professional actor (Gabara 2010). Bamba's experience as a griot may seem to situate his oral performance in the film in the specific context of the Mande cultural traditions of Mali, and raises important questions about the social and rhetorical function of these traditions in the contemporary context of neoliberal globalization. To address these questions, a brief assessment of the cultural and historical significance of the griot, and the contested idea of the screen griot in African cinema is in order. According to the 
ethnomusicologist Eric Charry, griot or guiriot was a term invented by French travellers to different parts of West Africa during the seventeenth century; the 'spelling became standardized to "griot"' in the late eighteenth century and was used to describe musical-verbal artisans who were often patrons of powerful political leaders (Charry 2000, pp. 105-108). Such Western claims to knowledge of the cultural significance of griot performances persist in more recent anthropological narratives. In an account of a griot-noble interaction, the anthropologist Barbara Hoffman (2000) describes how griots are thought to have 'the ability to manage occult powers which [they] manipulate principally through their control of language' (p. 12). Hoffman also claims that griots have functioned as mediators 'in personal, familial, and clan disputes' (p. 266).

The colonial provenance of the term griot and its subsequent usage in Western ethnographic discourse runs the risk of transforming the griot into an essentialist stereotype of West African oral cultures. Critical debates about African filmmakers as screen griots may further exacerbate this difficulty, not only because of a slippage from the West African cultural provenance of griots to a more general account of African cinema, but also in the suggestion that African film narratives are structured around an oral tale or narrative in which a central organizing figure, such as a griot, operates as a 'semantic filter' for the narration (Benali cited in Levine 2012, p. 154). In a discussion of Francophone African film, for instance, Melissa Thackway notes how prominent filmmakers such as Ousmane Sembène and Djibril Diop Mambety have both used the word griot to describe the public role of the filmmaker. In Sembène's view 'the artist must be the voice and ears of his [sic] people. In the modern sense, this corresponds to the role of the griot in traditional African culture' (Sembène cited in Thackway 2003, p. 58). In a similar vein, Mambety argues that 'the word griot is the word for what I do [...] and the role that the filmmaker has in society [...] the griot is a messenger for one’s time, a visionary and a creator of the future' (Mambety cited in Thackway 2003, p. 58). As 
Thackway makes clear, the griot may be a common cultural reference point for some West African filmmakers, but this not to suggest that West African filmmaking is defined exclusively by the oral traditions that the griot represents (p. 58). Indeed, a clear difficulty with such claims is that African cinema is framed as essentially different from French cinema, Soviet cinema or Hollywood cinema, and the complex and situated mediation of griot performances through the technologies and generic conventions of cinema are ignored. Such debates about the figure of the griot are certainly apposite to an understanding of Zegué Bamba’s oral performance in Bamako, but they do not specifically address the rhetorical function of this figure in relation to the neoliberal economic policies with which Bamako is centrally concerned. Indeed, to read Zegué Bamba's oral performance as that of a griot is to raise important questions about the social role and function of this figure in the context of a contemporary West African society that has been ravaged by the economic policies of the World Bank. Are we to read Zegué Bamba as a mediator for the indebted or the unemployed? What kind of power does the griot have in a postcolonial civil society without resources or infrastructure? And how is an audience unfamiliar with the language of Zegué Bamba’s oral performance to make sense of his public intervention, in the absence of a translator or subtitles? As Bamba performs his testimony before the court, the camera shifts from a focus on his face and body to the bodies and faces of the audience assembled in and around the courtyard. The silence of these figures assembled in the courtyard could be read as a lack of understanding. Indeed, in a brief discussion of this scene in an essay titled 'Rethinking Comparativism', Gayatri Spivak has described Bamba as 'the traditional healer who utters (apparently in a language not necessarily understood by the "native speakers"), (2012a, p. 477). Certainly, the absence of subtitles during this scene might suggest that the precise social and political significance of this man's words are lost on a cinematic spectator not familiar with the language of Bamba's performance. Yet the close-up shots on the individual 
faces of the audience assembled in the courtyard also imply that they are listening attentively to Bamba's performance. In this respect, the apparent failure of translation and communication at the meta-cinematic level of the foreign-language film spectator overlooks the possibility that the staging of Zegué Bamba's words as untranslatable in the frame of the film is itself a rhetorical strategy that positions Bamba as a singular, subaltern figure.

In her readings of postcolonial literary texts such as Jean Rhys’s Wide Sargasso Sea, J.M. Coetzee’s Foe, and Mahasweta Devi’s 'Pterodactyl', Gayatri Spivak (1999) has identified marginal, subaltern figures that she designates as 'curious guardians at the margin'. Figures such as the Martiniquan servant Christophine in Wide Sargasso Sea, Friday in Foe and the tribal cave painting in Devi’s 'Pterodactyl, Puran Sahay and Pirtha' may be understood as subaltern by virtue of their social, cultural or linguistic exclusion from the dominant fictional worlds evoked in each of these fictional texts. In Wide Sargasso Sea, Christophine is framed as the practitioner of obeah by the male English narrator; in Coetzee's Foe, Friday is represented as the victim of unspeakable colonial violence, which is embodied in the physical removal of his tongue; and in 'Pterodactyl, Puran Sahay and Pirtha', the subaltern character, Bikhia, is seen to protect tribal culture from commodification. In different ways, Spivak suggests that each of these figures also withhold their cultural knowledge and history from the colonizing gaze of a dominant culture. Christophine in Wide Sargasso Sea refuses the stereotypes of obeah that the colonial authorities use to criminalize and silence her; Friday in Foe cannot be accounted for within the terms of European systems of writing and representation that Susan Barton attempts to teach him, and withholds the cultural significance of his own cryptic inscriptions from Barton and from the reader; and the tribal character Bikhia in Devi's 'Pterodactyl, Puran Sahay and Pirtha' protects the cultural meaning of the cave drawing by withholding it from a dominant public sphere that might try to frame it as an anthropological object divested of cultural significance. 
There is a certain sense in which Zegué Bamba might also be read as the guardian for a language and culture that he articulates without translation or explanation. The film evokes a sense of the singular power of his oral performance by withholding the meaning of what he says from the subtitles. Indeed, he could be read as a custodian for a subaltern language and cultural practice that has been marginalized by dominant global languages such as English or French - the very language of the courtroom (see Menozzi 2014). And by drawing attention to this process of cultural and linguistic marginalization, the film encourages viewers to engage with the singularity of the man's words and gestures. If for Gayatri Spivak, the singularity of the subaltern is defined in part by the incommensurability between the speech acts of the subaltern and the discourse and values of dominant political institutions, Bamako enjoins viewers to read Bamba's performance as an attempt to contest the dominant discourse of the law, which both permits and proscribes his participation in the dominant public sphere. Of course, the film's staging of untranslatability could be seen to run the risk of denuding Bamba's performance of its cultural and historical specificity, and fetishizing his performance as trope for a certain idea of authenticity that cannot be understood in the dominant codes of the public sphere as they are defined by the procedures of the trial. Yet in foregrounding what Gayatri Spivak has called 'the necessary impossibility' of translation (2012, p. 270), the film also encourages viewers to reflect on the wider social and economic forces that exclude many of the characters in the film from participation in civil society. Indeed, it is significant that Aissata Tall Sall, the Malian lawyer who represents the prosecution in the people’s case against the World Bank, invokes Zegué Bamba’s performance in her closing statement:

This people, Your Honour, is Zegué Bamba. Have you heard Zegué Bamba’s lament, Your Honour? 
This peasant who asks, ‘why don’t I sow any more? When I sow, why don’t I reap? Why don’t I eat when I reap?'

This Africa, Your Honour, is asking you with dignity, humility and modesty, but with legitimacy, for justice.

In this speech, Sall offers a periphrastic translation of Bamba’s words, which seems to demystify the earlier framing of his speech as an untranslatable sign of a West African oral tradition. By defining his economic status as a peasant farmer in the social world evoked by the film, Sall clearly represents Bamba as a subaltern figure who cannot represent himself in the codes and conventions of this fictional courtroom. What is more, by posing the question 'Have you heard Zegué Bamba’s lament, Your Honour?', Sall implies that neither the judge nor the European lawyers in the courtroom have understood Bamba's words. In so doing, Sall takes on the role of a native informant for both the people assembled in the court and the cinema audience. This is an ambivalent role. On the one hand, Sall speaks the dominant language of international civil society from which Bamba is excluded, and in the very act of translating his words, she may seem to exacerbate his formal exclusion from civil society as a subaltern figure. On the other hand, by translating Bamba's words, Sall attempts to transform the space of the court into a counterpublic space in which orature can be recognized and valued as an appropriate mode of public address. Indeed, Sall's suggestion that Bamba's oral performance was a 'lament' for a means of production in which he was able to make a living from the proceeds of his farming also re-frames his performance as a form of testimony and a demand for justice. What is also interesting about Sall's address to the court is the way in which she equates Zegué Bamba with 'the people' and 'Africa'. This use of synecdoche - in which Bamba is both a constituent part of 'the people' and 
'Africa', on the one hand, and a figure who represents both 'the people' and 'Africa' as a whole, on the other - draws attention to the limitations and possibilities of civil society as a meaningful space for contesting the economic policies of the World Bank and the damage they have wrought on African societies such as Mali.

For Jean and John Comaroff (1999), the founding inequalities of the European enlightenment idea of civil society are further exacerbated by the contemporary global rise of neoliberal finance capitalism - an economic ideology that has devalued currencies, eroded national sovereignty over infrastructure and public finances, and undermined the capacity of states to support an active public sector. One of the main institutional actors in the reproduction of that ideology is the World Bank. As Bret Benjamin explains:

Although different Bank regimes have varied (sometimes substantially) in the degree to which they have believed markets should be regulated or left alone to correct themselves, or the degree to which redistributive policies or inducements to privatization might be necessary, a consistent belief in the steadfast bond between progress and capitalist economic growth has never waivered. The Bank's faith is so resolute that in its public assertions capitalism goes largely unspoken: the concept functions as common-sense logic and economic law, the coherent, foundational principle on which a flexible, responsive, contingent conception of development can be built and perpetually renovated (2007, p. 7).

If the 'bond' between capitalist economic growth and development is axiomatic for the World Bank, it is precisely this axiom that Bamako calls into question through its evocation of a socioeconomic world which has been ravaged by the Bank's structural adjustment policies towards debtor nations in the Global South. True, the World Bank was not always regarded as one of the 
main agents of the debt crisis that ruined the economic and social fabric of African countries such as Mali during the 1980s and 1990s. As Benjamin has argued, the archives of the World Bank reveal an institution that historically imagined itself as a development agency that provided aid to underdeveloped economies during the Cold War. Yet such a narrative of the Bank as a benign development agency was called into question in the aftermath of the debt crisis of the 1970s when the Bank began to profit from its loans to developing countries - a practice that laid bare 'the illusion of development "aid”' and the 'historical role [of the World Bank] as a neo-colonial mechanism for the transfer of wealth from South to North' (Benjamin 2007 p. 136).

The World Bank first introduced structural adjustment policies in the early 1980s. These policies included economic reforms such as currency devaluation, reductions in public spending, and the liberalization of foreign trade. Such policies were initially presented as a rational solution to debt management for developing economies (Walton and Seddon 1994, pp. 17-18). Yet what started out as a temporary solution to a 'balance of payments crisis' (ibid.), later became a technique of fiscal governance in which neoliberal economic policies were implemented across the developing world as a condition of World Bank loans. Within the specific context of Mali, the economic policies of the World Bank and the IMF coincided with democratic demands for political and economic reform. Stephen P. Riley and Trevor W. Parfitt note how supporters of structural adjustment programs, such as the former British minister for overseas development, Lynda Chalker, have tended to conflate the neoliberal market principles that underpinned its loans to Sub-Saharan African countries such as Mali with the liberal rhetoric of human rights and principles of democratic accountability (Riley and Parfitt 2008, pp. 136-137). Certainly, the World Bank sought to reform public sector expenditure as a condition of its structural adjustment loans to Mali. In a report written by the President of the International Development Association to the Executive Directors of the World Bank on a Proposed Development Credit to the Republic 
of Mali for a Structural Adjustment Credit (1990), there is a reference to a 'Public Enterprise Sector Adjustment Program', the stated aims of which were:

(a) reform of key economic policies regarding public investment expenditure and economic incentives, (b) financial sector reforms, including restructuring the largest commercial bank, (c) institutional and legal reform of the relations between government and public enterprises, and (d) rationalization of the sector through restructuring and divestiture (p. 7).

The report makes no explicit reference to the political situation in Mali or to the demands for political change. Indeed, one of the primary concerns of this document is to demonstrate how the government of Mali has reduced its public sector expenditure in order to justify the case for a structural adjustment loan. Yet in a later country report on Mali written for the International Monetary Fund in 2002, the transition from a state-controlled economy to an economy based on market forces is explicitly linked to political changes in the government:

The Malian government started implementing structural adjustment policies in 1986, prompted by disappointing economic performance, which was exacerbated by a serious drought over the 1982-85 period. Mali’s adjustment efforts gained the financial support of the fund in 1988, with the adoption of a policy framework paper and strong medium term macroeconomic policies designed to stabilize the economy, prepared in consultation with the Fund and the World Bank. To add new impetus to this effort, starting in the early 1990s, with the change of political regime to a democratic system, the government decided to transform and modernize the economy, from a state controlled system into one 
increasingly governed by market forces in the context of Fund- and Bank-supported programs (p. 9).

One possible reading of this statement is that Mali's transition to a neoliberal economic system is causally connected to its political transition to a liberal democracy. What such a reading overlooks, however, is the sovereign power and influence of the World Bank and the International Monetary Fund over the social and economic life of Mali. Such power was further consolidated by the devaluation of French West African currency in 1994. As Manthia Diawara explains:

On January 20, 1994, European and American financial institutions imposed an expected but long-resisted currency devaluation on Francophone Africa that rendered export goods and labor in the region cheaper and more attractive to international corporations. Nigeria, Zaire, and Ghana had gone through the same process in the 1980s. Such "structural adjustment programmes,” the World Bank and other financial experts argue, by attracting investors to devalued products and people, create business roles for Africans who have been excluded for decades from the scene of global economics. (Diawara 2003, pp. 6465)

Rather than creating new business roles for Africans, however, the narrative structure of Bamako suggests that the World Bank's structural adjustment policies and the devaluation of the CFA Franc have destroyed the socio-economic fabric of Mali. By focalizing the Bank's structural adjustment policies through the consciousness of different characters whose lives and livelihoods have been affected by these policies, the film offers a counterpoint to the Bank's neoliberal rhetoric of economic growth as a solution to debt and poverty. In this sense, the film articulates 
the material reality of structural adjustment from the standpoint of the dispossessed. By framing this knowledge and experience in the space of a fictional courtroom, the film may seem to encourage viewers to reflect on the emancipatory potential of civil society to deliver social and economic justice to the oppressed. Indeed, such a representation of civil society may seem consistent with Antonio Gramsci’s claim that 'the history [of the subaltern classes] is intertwined with that of civil society' (Gramsci 1971, p. 202). Yet this would be to overlook the way in which civil society is also a space for economic exchange - a point that Gramsci made in his reflections on ‘laissez-faire liberalism’. As John Beverley explains:

The core idea of laissez-faire liberalism is, Gramsci writes, that 'economic activity belongs to civil society, and that the State must not intervene to regulate it'. But $[\ldots]$ 'in actual reality civil society and the State are one and the same', since 'laissez-faire too is a form of State "regulation", introduced and maintained by legislation and coercive means' (Beverley 1999, p. 118).

Just as Gramsci was under no illusions about the autonomy of civil society from the forces of capital and the state, so Bamako stages questions about the political meaning and function of civil society in the space of the courtroom. As a spatial trope of the law, the courtroom symbolizes a certain liberal democratic ideal of civil society in which individuals seek to claim their social and economic rights before the law. Yet the witnesses who take the stand in the case against the World Bank also foreground the limitations of participation in the dominant institutions of civil society as an effective strategy for addressing the depredations of structural adjustment. We have already seen, for instance, how the unemployed schoolteacher, Samba Diakité, is either unable or unwilling to speak when he takes the witness stand in the trial. As an unemployed teacher, one 
might have expected Diakité to offer some reflections on the relationship between the closure of the school in which he worked and the World Bank's policies of requiring debtor nation states to cut public sector spending as a condition of receiving loans. That he does not do so may teach us something about the ways in which the codes and conventions of the law are powerless to challenge the neoliberal economic policies that have already stripped away the institutions of Mali’s civil society, exemplified here by the closure of a school.

What then are we to make of the film's representation of this fictional trial of the World Bank? From the very beginning, the film self-consciously frames the artificiality of the trial. There are four video cameras positioned on tripods around a residential courtyard; each one of these cameras is captured within the frame of another camera. Furthermore, the microphones involved in recording the witnesses' testimonies before a panel of judges are also visible. By placing these recording technologies within the cinematic frame-of-reference, viewers are clearly made aware that the trial narrative is a cinematic construct. What is more, the location of the courtroom in a residential courtyard raises questions about the authority and legitimacy of the judiciary. As Matthew J. Christensen notes:

In its most mainstream manifestations, the courtroom drama is invested in and supported by the political-juridical formation of a sovereign nation-state willing and able to guarantee the protection of the law to legally recognizable victims through the orderly, rational operations of the judiciary. The court's dislocation to a residential compound immediately calls the judiciary’s authority into question (2013, p. 114).

By locating the courtroom in the courtyard, in other words, Sissako suggests that the judiciary 
and the civil society it represents are a simulation of a sovereign nation state that has been mortgaged to repay its debts to the World Bank. Such a simulation may be understood in relation to the specific historical context of the film's production, situated as it was in the aftermath of the World Social Forum in Bamako in January 2006. The World Social Forum was initially conceived as an open space for global justice activists to organize forms of collective resistance to the neoliberal economic policies of governments, international financial institutions and multinational corporations. However, the political legitimacy of these events has also been jeopardized by the use of the language of global civil society - especially 'the open space/ public square metaphor' (Benjamin 2007, p. 201). The problem with such metaphors, as Bret Benjamin explains, is that they are easily appropriated by institutions such as the World Bank who seek to present themselves as partners in the struggle against poverty and hunger while continuing to impose economic policies that exacerbate poverty and hunger in the indebted societies over which they assert sovereignty and control. In the context of postcolonial societies such as Mali, the colonial genealogy of civil society and the historical exclusion of the colonized from the rights and freedoms associated with the democratic ideals of the European enlightenment raises profound questions about the political efficacy of civil society to address the economic conditions of debt and poverty. Such political impotence is even more pronounced in the aftermath of structural adjustment where the postcolonial state and its civil society have, to paraphrase Matthew Christensen, been re-ordered to serve the market interests of global capitalism. It is precisely this failure of civil society to protect the victims of structural adjustment that Bamako foregrounds in its self-conscious staging of the trial as a simulation of civil society. As Christensen puts it: 'by agreeing to a trial as a vehicle for securing justice, the elite Africans who participate consent to "the ruling episteme, the ruling rationality" designed to serve the interests of institutions like the film's defendants and otherwise secure private property rights over human 
survival' (2013, p. 115). The irony of this spectacle is that the trial of the World Bank does little to challenge the 'ruling rationality' of structural adjustment that is ostensibly on trial.

If the courtroom in the courtyard encourages viewers to think about the performativity of law, then it does so in order to raise questions about the limitations of the law and civil society as a framework for delivering economic justice and basic human rights to the people of Mali after the neoliberal reordering of the postcolonial state and its imperative to economic self-governance. As a counterpoint to the failures of civil society represented in the film by the mise-en-scène and narrative trajectory of the trial, Bamako traces the everyday lives and experiences of the people in the courtyard who have been subjected to what Rob Nixon has called the slow violence of neoliberalism. Nixon connects the slow violence of neoliberalism to the 'slowly unfolding environmental catastrophes' associated with climate change (2010, p. 2). Such a consideration is, of course, important, but it can also overlook other forms of slow violence such as the infrastructural failure of the neoliberal state to provide for the unemployed and the sick. Indeed, a consideration of the slow violence of neoliberalism can help to shed light on the processes by which the subaltern is constituted in and through their exclusion from capital logic. In Bamako, this slow violence is registered through the supplementary narrative of Melé and Chaka's disintegrating marriage - a narrative that takes place in the courtyard. On first viewing, it may seem that the close up shots of Melé doing her hair and getting ready to go out are discontinuous with the intellectual discussions about politics, economics, and African poverty that take place in the trial. Indeed, Melé seems indifferent to these discussions as she goes about her daily life. But as the film develops, we gradually realize that Melé and Chaka are drifting apart. The camera repeatedly moves between a close-up shot of a wedding photograph of Melé and Chaka to a focus on the way in which they are not communicating. Chaka seems to be brooding in the courtyard while Melé prepares to perform as a solo vocalist in nightclubs, and we see different men tying 
up Melé's dress in the courtyard at the start of each day. One possible reason for the breakdown of Melé and Chaka’s relationship is that Chaka is unemployed. As Bret Benjamin puts it, 'Chaka, like the former schoolteacher, is a permanent member of the reserve army of labor, a category itself that seems inadequate to account for the explosive growth of chronic unemployment and underemployment throughout much of the Global South [...]' (2012, p. 218). That Chaka takes his own life at the end of the film could be read as a response to the slow violence of a neoliberal state that abandons its own citizens to a precarious life of economic self-governance. By suggesting that Chaka's tragic death at the end of the film is a desperate response to structural adjustment, in other words, the film encourages viewers to reflect on the contemporary socioeconomic processes that relegate the subaltern to a subject position outside capital logic. In the context of wider debates about the theory and methodology of the Subaltern Studies collective, and its possible relevance to situations as diverse as postcolonial India and contemporary Francophone West Africa, it might be tempting to look for structural parallels between Chaka's suicide and the circumstances of Bhubaneswari Bhaduri's death recounted by Gayatri Spivak in 'Can the Subaltern Speak?' Certainly, the desperate and tragic act of taking one’s life in the face of unbearable social, political or economic conditions presents a methodological challenge to historians seeking to understand those conditions from the singular perspective of the person that commits suicide. And, just as Gayatri Spivak powerfully conveys the way in which Bhubaneswari Bhaduri's desperate act performed the impossibility of her acting and speaking as a subject of history, so Sissako encourages viewers to draw connections between Chaka's suicide and the economic policies that seem to define wageless life as a life without meaning or value.

This is not to imply, however, that death is the only form of agency available to the subaltern in the face of neoliberalism's attritional violence. As Michael Denning has argued in an essay on 'Wageless Life', '[t]o speak repeatedly of bare life and superfluous life can lead us to 
imagine that there really are disposable people, not simply that they are disposable in the eyes of state and market' (2010, p. 80). Against such a conceptual error, Denning suggests that 'wageless life, not wage labour, is the starting point in understanding the free market' (p. 81). Put another way, wageless forms of life are the norm rather than the exception in the contemporary neoliberal economic order. Denning's reflections on wageless forms of life and work may echo the arguments of Italian post-operaist thinkers such as Mario Tronti and Antonio Negri. In his account of social capital, for instance, Tronti (1973) suggests that the distinction between life and work has been increasingly blurred by the current mode of advanced capitalist production, in which capitalist relations have subsumed all forms of human social activity. In this mode of advanced capitalist production since the 1970s, labor time is no longer the measure by which value is calculated; instead, the emergence of new forms of social and immaterial labor has rendered the distinction between waged and unwaged work increasingly indeterminate. In advanced Western capitalist societies, wagelessness has certainly become an increasingly visible feature of contemporary social life. Yet in their account of the social factory, theorists such as Tronti and Negri presuppose the figure of the waged factory worker of Western industrial capitalist societies as a normative political subject - a subject that can be traced to one of the main sources of their thought: Marx's 'Fragment on Machines'. The difficulty with such a presupposition is that it overlooks the ways in which such a new mode of production in advanced Western capitalist societies is bound up with the dispossession and exploitation of subaltern populations in the Global South - a process that is aided and abetted by global financial institutions such as the World Bank and the International Monetary Fund (Caffentzis 1998). By contrast, Denning questions the marginalisation of unemployment in Marx’s analysis of industrial capitalism in order to suggest that wageless life, rather than wage labor, is the norm for much of the world's population. 
Denning does not specifically refer to Gramsci’s account of the subaltern or to the work of the South Asian Subaltern Studies collective in his account of wageless life. Yet his reflections on the conceptual and political challenges that wageless life presents to Marxist social theory can productively recalibrate the methodology and focus of the Subaltern Studies project. In an extended discussion of the work of the Indian Self Employed Women's Association (SEWA), Denning identifies how this union represented 'a world of wageless work which was invisible to the labour apparatuses of the state' (2010, p. 92). This invisibility may help to account for the way in which the subaltern is positioned outside of capital logic. One of the ways in which this wageless work has been represented is with reference to the spaces in which this labor takes place. As Denning puts it, 'organizations of workers in the so-called informal sector have mapped their world less by its relation to a formal state-regulated economy than by its workplaces, particularly the street and the home' (p. 95). This reference to such spaces of wageless work may seem unremarkable in and of itself. Yet it points towards a different way of thinking about wagelessness that is apposite to my reading of Bamako. If the narrative of Chaka's unemployment and death seems to reinforce a stereotype of wageless life as wasted life (Denning 2010, p. 96), the film's visual references to the weaving and dyeing of cotton in the courtyard may appear to evoke a space of wageless life and work that the capitalist world system does not recognise. This may seem surprising when one considers that historically, cotton production was central to the global expansion of capitalist markets during the European colonial era. As Isaacman and Roberts explain:

The cotton textile industry was a central consumer production sector in all of the European nations that scrambled to control African territories in the late nineteenth century. Not surprisingly, cotton held a primary place in European colonial agricultural 
policies throughout Africa (1995, p. 1).

In French colonial Soudan (Mali), raw cotton was a valuable commodity for the French metropolitan market; it was also central to colonial governmentality. As Richard Roberts (1996) has argued, the French colonial administration's introduction of cotton fairs in Soudan during the 1920s provided a technique for controlling the free market in cotton: 'It was an institution designed to exert control over the supply and marketing of cotton, to ensure quality, and to protect buyers and sellers alike' (p. 183). Yet the paradox in French colonial policy, which decreed that African producers could only sell cotton at official cotton fairs while retaining the right not to sell if the price was not acceptable to the seller exemplified how the French colonial state 'had created a grotesque caricature of free markets' (ibid.). So-called cotton colonialism may certainly be understood as a crucial aspect of Africa's incorporation into the world market system in the $19^{\text {th }}$ and $20^{\text {th }}$ centuries. Yet, as Immanuel Wallerstein (1991) has argued, the geographical shift of textile production from the core to the periphery of the world market system and the decline in the world market value of cotton that took place between the early $19^{\text {th }}$ century and the early $21^{\text {st }}$ century might suggest that cotton colonialism is a thing of the past. This is not to suggest, however, that the imperialist dynamics of cotton production have entirely disappeared in the contemporary era of neoliberal globalization. On the contrary, as William G. Moseley (2008) has argued, cotton production in Mali is a crucial source of wealth to a government that is subject to the structural adjustment programs of the World Bank and the IMF.

Textiles and textile production form a crucial part of the framing shots of the courtyard in Bamako, and yet the history and political economy of textile production is not explicitly addressed in the trial. For Jacqueline Maingard, the film's references to the activity of cotton weaving and dyeing are a further sign of how 'global financial policies are squeezing out these 
forms of local economic enterprise, sapping African society of its locally based forms of livelihood as well as its cultural heritage' (p. 399). Such a reading of the visual references to textile production in Bamako as a 'locally based [form] of livelihood' is quite compelling, but in suggesting that the images of cotton dyeing are a visual metaphor for the effects of structural adjustment on the social fabric of Mali, Maingard overlooks the ways in which these scenes of textile labor in the courtyard might also create a supplementary space that circumvents the dominant discourse of civil society represented by the trial in the courtyard. Indeed, it is significant that one of the static, close up shots of the audience who listen to Zegué Bamba's performance in the courtyard focuses on a woman who stands between two makeshift washing lines suspended from which are two large pieces of dyed cloth. In so doing, the film suggests a connection between the material conditions of this woman's work and Bamba's reflections on the injustice of World Bank policies. The narrative of the trial itself does not give voice to the colonial history of textile production, to the value of cotton dyeing in the contemporary global economic system, or to women's involvement in that economic system. Yet by making such spaces of gendered work visible, Bamako raises questions about the meaning and value of such labor practices in an era of neoliberal globalization. Are we to read such visual references to textile production as a sign of the way in which structural adjustment has encouraged local enterprise at the expense of waged forms of public sector work such as teaching? And how might such spaces of labor contribute to a rethinking of the public sphere from the standpoint of the subaltern? Can such labor practices be meaningfully understood as subaltern if they are incorporated into the global economic system? Or is there a way in which such forms of informal or unwaged work stand outside capital logic? Questions such as these mark the limits of the film's political narrative. Yet they also highlight the ways in which different experiences of wageless life and work necessitate a rethinking of subalternity as an economic condition as well 
as a political category.

In a recent discussion of Gramsci's account of the subaltern in the Prison Notebooks, Gayatri Spivak posits that Gramsci was proposing a new methodology in which the intellectual learns to learn from the subaltern in a mediated way (Spivak 2012b, p. 223). This use of a pedagogical analogy to rethink the political relationship between the intellectual and the subaltern is apposite to an understanding of Bamako's structure of public address. Against the benevolent European lawyers who purport to speak for the witnesses in the case against the World Bank, the film encourages viewers to question the democratic promise of civil society to represent the wageless life of a subaltern population that has been abandoned by a neoliberal state in the aftermath of structural adjustment. Such failures are clearly exemplified in the connections that the film draws between the tragic narrative of Melé and Chaka and the slow violence wrought by the economic policies of the World Bank, which the trial is powerless to address. Yet at the same time, the film’s framing of Zegué Bamba as a mediator for the indebted and the unemployed contributes to the invention of a supplementary, subaltern space in the courtyard that exceeds the legal codes and conventions of the trial. Like Bamba's oral performance, the film's visual references to cotton dyeing create a parallel space that is contiguous with the court, but not a part of it. Such spaces certainly exemplify the fraught relationship between the social world of the subaltern and the dominant structures of civil society from which they are by definition excluded. But they also gesture towards a new vocation for Subaltern Studies: to trace the socioeconomic conditions of an indebted, wageless life, and to address the epistemological challenge that such a condition poses to our understanding of capitalism. Such an approach may also involve a rethinking of the ways in which neoliberalism has altered the predominant conception of the subaltern, as Antonio Gramsci, Gayatri Spivak, and the Subaltern Studies collective have defined it. It may, for instance, involve a consideration of 
the ways in which the exclusionary grounds of representation are shaped by economic determinants such as debt and precarity. Indeed, as this article has tried to suggest, it is only by tracing the economic conditions of debt and wageless life that one can begin to understand the double bind which both limits and enables the contemporary subaltern's (non)passage into hegemonic structures of representation. Gayatri Spivak has suggested in her reflections on "Can the Subaltern Speak?” that the singular position of the gendered subaltern in colonial India cannot be accommodated within the hegemonic terms of representation in both its aesthetic and political senses (Spivak 2010, pp. 230-36). In contrast to Antonio Gramsci, who referred to the subaltern as a social class, Spivak's distinctive contribution to subaltern studies was to emphasise how the singular figure of the subaltern woman does not register in collective political narratives such as that of the global class struggle or national liberation (Young 2012). It is in this context that Spivak's ethical critique of subaltern consciousness and representation needs to be understood. Yet if the subaltern stands in a relation of radical alterity with respect to hegemonic forms of representation, it is also important to emphasise that the political task of representation has not simply 'withered away', as Spivak herself emphasizes in the conclusion to 'Can the Subaltern Speak?' (308). In this respect, Spivak's deconstructive critique of representation could be seen to parallel Enrique Dussel's formulation of an ethics of liberation for the 'victims of the world system of globalized exclusion' (2013, p. xv). Such an ethically nuanced approach to representation has important implications for the reading of Bamako presented in this essay. The critique of international civil society as a public space for contesting the political rationality of neoliberalism that is staged in the mise-en-scene of Bamako may foreground how subalternity understood as a radical space of difference - fractures the hegemonic frame of political representation (Drabinski, pp. 50-87). In so doing, the film also marks the scandalous failure of predominant forms of political representation to do justice to the wageless life of the 
contemporary subaltern on the periphery of the capitalist world system. Yet in marking this failure of representation to make any meaningful difference to the material conditions of the people depicted in the film, Bamako also inscribes an ethical demand for a more appropriate form of representation that responds to the singularity of the lives and bodies of the victims of the capitalist world system.

\section{References}

Benjamin, B. (2007) Invested Interests: Capital, Culture and the World Bank, Minneapolis, University of Minnesota Press.

Benjamin, B. (2012) 'Bamako and the Problem of Anti-Imperial Art', in The Megarhetorics of Global Development, eds. R. Dingo and J. Blake Scott, Pittsburgh, University of Pittsburgh Press, pp. 199-232.

Beverley, J. (1999) Subalternity and Representation: Arguments in Cultural Theory, Durham, Duke University Press.

Caffentzis, G. (1998) 'The End of Work or the Renaissance of Slavery? A Critique of Rifkin and Negri', presented at the 'Globalization from Below' conference, Duke University, February 6, 1998, available online at http://www.ecn.org/finlandia/autonomia/theend.txt.

Charry, E. (2000) Mande music: Traditional and Modern Music of the Maninka and Mandinka of Western Africa, Chicago, University of Chicago Press.

Christensen, M.J. (2013) 'African Popular Crime Genres and the Genres of Neoliberalism', Social Text, vol. 31, no. 2, pp. 103-21.

Comaroff, J. and Comaroff, J. (1999) 'Introduction', in Civil Society and the Political Imagination in Africa: critical perspectives, eds. J. Comaroff and J. Comaroff, Chicago, University of Chicago Press, pp. 1-43. 
Denning, M. (2010) Wageless Life, New Left Review, vol. 66, pp. 79-97.

Diawara, M. (2003) 'Toward a Regional Imaginary in Africa', in World Bank Literature, ed. A. Kumar, Minneapolis, University of Minnesota Press, pp. 64-65.

Drabinski, J. (2011) Levinas and the Postcolonial: Race, nation, other. Edinburgh: Edinburgh University Press.

Dussel, Enrique. (2013) Ethics of Liberation in the Age of Globalization and Exclusion, trans. Eduardo Mendieta, Camilo Pérez Bustillo, Yolanda Angulo, and Nelson MaldonadoTorres. Durham, N.C.: Duke University Press.

Gabara, R. (2010) ‘Abderrahmane Sissako: Second and Third Cinema in the First Person’, in Global Art Cinema: New Theories and Histories, eds. R. Galt and K. Schoonover, Oxford, Oxford University Press, pp. 320-333.

Gramsci, A. (1971) Selections from the Prison Notebooks, trans. Q. Hoare and G. Nowell Smith, London, Lawrence and Wishart.

Hoffman, B. (2000) Griots at War: Conflict, Conciliation, and Caste in Mande, Bloomington, Indiana University Press.

International Monetary Fund (2002) Mali: Selected Issues and Statistical Annex, Washington, International Monetary Fund.

Isaacman, A and Roberts, R. (1995) 'Cotton, Colonialism and Social History in Sub-Saharan Africa', in Cotton, Colonialism and Social History in Sub-Saharan Africa, eds. A. Isaacman and R. Roberts, Oxford, James Currey, pp. 1-42.

Levine, A. (2012) 'Words on Trial: Oral Performance in Abderrahamane Sissako’s Bamako', Studies in French Cinema, vol. 12, no. 2, pp. 151-167.

Maingard, J. (2010) ‘Screening Africa in Colour’, Screen, vol. 51, no. 4, pp. 397-403.

Menozzi, F. (2014) Postcolonial Custodianship: Cultural and Literary Inheritance, London, 
Routledge.

Nixon, R. (2010) Slow Violence and the Environmentalism of the Poor, Cambridge, Mass., Harvard University Press.

Riley, S.P. and Parfitt, T.W. (2008) 'Economic Adjustment and Democratization in Africa', in Free Markets and Food Riots: The Politics of Global Adjustment, eds. J. Walton and D. Seddon, Oxford, Blackwell, pp. 135-170.

Roberts, R. (1995) 'The Coercion of Free Markets: Cotton, Peasants, and the Colonial State in the French Soudan, 1924-1932', in Cotton, Colonialism and Social History in Sub-Saharan Africa, eds. A. Isaacman and R. Roberts, London, James Currey, pp. 221-246.

Roberts, R. (1996) Two World of Cotton: Colonialism and the Regional Economy in the French Soudan, 1800-1946, Stanford, Stanford University Press.

Sissako, Abderrahmane (2006) Bamako, (film).

Spivak, G. C. (1985) 'Scattered Speculations on the Question of Value’, Diacritics, vol. 15, no. 4, pp. 73-93.

Spivak, G. C. (1988) 'Can the Subaltern Speak?' in Marxism and the Interpretation of Culture, eds. L. Grossberg and C. Nelson, Urbana, University of Illinois Press, pp. 271-313.

Spivak, G. C. (1996) 'Subaltern Talk: Interview with the Editors', in The Spivak Reader, eds. D. Landry and G. McLean, London: Routledge, pp. 287-308.

Spivak, G. C. (1999) A Critique of Postcolonial Reason: Towards a History of the Vanishing Present, Cambridge, Mass., Harvard University Press. 
Spivak, G. C. (2010) Can the Subaltern Speak? Reflections on the History of an Idea, ed. Rosalind C. Morris. New York, NY: Columbia University Press.

Spivak, G. C. (2012a) An Aesthetic Education in the Era of Globalization, Cambridge, Mass., Harvard University Press.

Spivak, G. C. (2012b) 'Interview with Gayatri Chakravorty Spivak', in The Postcolonial Gramsci, eds. Neelam Srivastava and Baidik Bhattacharya, London, Routledge, pp. 221232.

Thackway, M. (2003) Africa Shoots Back: Alternative Perspectives in Sub-Saharan African Film, Oxford, James Currey.

Tronti, M. (1973) 'Social Capital’, Telos, vol. 17, pp. 98-121.

Wallerstein, I. (1991) World Systems Analysis: An Introduction, Durham, Duke University Press.

Walton, J. and Seddon, D. (1994) Free Markets and Food Riots: The Politics of Global Adjustment, Oxford, Blackwell.

Young, R.J.C. (2012) 'Il Gramsci meridionale’, in The Postcolonial Gramsci, eds. Neelam Srivastava and Baidik Bhattacharya, London, Routledge, pp. 17-34. 